\title{
Professors' Politics and Their Appeal as Instructors
}

Jason Giersch, University of North Carolina at Charlotte

ABSTRACT As more universities view students as customers and as more critics accuse universities of political bias, it is important to learn how students respond to professors' politics. Does a politically active professor make a course more or less appealing? In this experiment, I randomly presented descriptions of course instructors to current university students and asked them to describe their appeal. Subjects expressed greater interest in professors who were politically ambiguous or whose politics matched their own. Conservative professors were more polarizing than liberal professors, and liberal students rejected conservative professors more than they preferred liberal professors. Based on these results, political neutrality is the safest bet for attracting a broad set of students, especially when a professor is conservative.

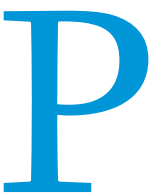

rofessors in American universities tend to be more politically liberal than the population overall, raising concerns about indoctrination among generations of conservatives (Bloom 1987; Buckley 1951; Horowitz 2010; Shapiro 2010) and mainstream media (Friedersdorf 2012; Shields and Dunn 2016; Wooldridge 2005). Research suggests that these concerns have been overstated because university faculty have been found to be more politically diverse and less radical than some portrayals suggest (Gross and Simmons 2014); faculty ideology has little, if any, effect on student ideology (Mariani and Hewitt 2008; Woessner and Kelly-Woessner 2009). Still, less is known about whether the expression of professors' political ideologies is welcome among students who, nationally speaking, tend to self-identify most often as moderates, then as liberals, and least often as conservatives (Eagan et al. 2017). Do students avoid partisan professors?

\section{BACKGROUND}

There is an enduring fascination with the politics of both students and professors on American campuses. A recent national survey of college students found that liberalism is growing in popularity and more students feel eager to protest on typically liberal policy issues, including affirmative action, legalization of marijuana, and abortion rights (Eagan et al. 2017). Assessments of faculty ideologies occur regularly, revealing that professors tend to be liberals, especially in the social sciences (Gross 2013; Gross and Simmons 2014).

The generalization that college campuses are venues for liberal professors to indoctrinate liberal students has spawned numerous empirical studies about students' perceptions of their

Jason Giersch ${ }^{(\mathbb{D})}$ is assistant professor of political science and public administration at the University of North Carolina at Charlotte. He can be reached at jgiersch@uncc.edu. professors' politics. O'Brien and Pizmony-Levy (2016) found that students are more impressed by professors whose research engages with activism, even when that activism suggests liberal leanings. A study by Woessner and Kelly-Woessner (2009) suggested that although professors are rarely able to conceal their politics from students, an observed shift to the left by students was unrelated to their professors' ideologies. In other studies, Kelly-Woessner and Woessner $(2008 ; 2006)$ found that students learn more from and give higher evaluations to professors whose ideologies match their own, putting conservative professors at a disadvantage.

However, less is known about how professors' politics make their classes more or less attractive to students. Research on which professor characteristics students prefer has shown cognitive traits to be important. Among them, communication, organization, and teaching skills are most preferred by students (Miron and Segal 1978; Slate, LaPrairie, and Onwuegbuzie 2009; Young and Shaw 1999). Students also like professors who are challenging and knowledgeable, connect content to students' lives, and respect their ideas (Acker 2003). Thus, professors with histories of political activism could be attractive to a student of political science because they likely would bring a passion for the content and share experiences that make the content more real. In turn, generating student interest makes achieving educational success more likely (Tinto 2017). At the same time, fairness also is a valued trait (Slate, LaPrairie, and Onwuegbuzie 2009), and students may fear that politically active professors will not treat fairly students with opposing views.

The salience of the current political climate (Abramowitz and Webster 2018) as well as the treatment of students as customers (Barr and Turner 2013) give importance to the issue, as do the competing interests within higher education (Rothman, KellyWoessner, and Woessner 2010). This study asks whether a course 
becomes less attractive to students when the instructor is a known partisan. It also explores how students' political outlook affects their interest in these professors. These questions are important for faculty in making decisions about maintaining political neutrality in their teaching, for institutions concerned about the political climate on campus, and for those concerned about academic freedom (Gormley-Heenan 2012). being a political science major, having interest in politics or current events (measured by the number of times per week they consumed news other than sports), leaning left or right (on a scale of 1 to 7 , extremely liberal to extremely conservative), ${ }^{1}$ or gender. Therefore, I controlled for those variables in ordered logit regression models, with reported degree of interest ( 1 through 5 ) in taking an unspecified course with the professor as the dependent variable. I tested

\section{This study asks whether a course becomes less attractive to students when the instructor is a known partisan.}

\section{HYPOTHESES}

Three hypotheses were tested. First, students may be wary of partisan professors. This neutrality hypothesis $\left(\mathrm{H}_{1}\right)$ assumes, as Horowitz (2010) argued, that students would find it undesirable for ideological teachers to bring politics into the classroom. A second hypothesis states that students may welcome an ideological professor when their ideologies agree (Kelly-Woessner and Woessner 2006, 2008). Under this political tribalism hypothesis $\left(\mathrm{H}_{2}\right)$, students prefer professors who share their ideologies and avoid those with opposing views. A third hypothesis argues that because liberal professors are so common, a conservative professor would be a welcome change. With a nod to an editorial from Georgetown University's student newspaper calling for the hiring of more conservative professors, this "Hoya" hypothesis $\left(\mathrm{H}_{3}\right)$ suggests that students who are liberal, moderate, or conservative would welcome a chance to learn more from a conservative point of view.

\section{METHODS}

I tested these hypotheses with an experiment in which college students were asked to read a description of a fictitious political science course followed by a randomly assigned description of the instructor and then answer questions about their interest in the course, their interest in another course with the instructor, and their perception of the instructor's expertise. For a touch of realism, the instructor's name was redacted and only the title "Dr." was presented, as though the course and instructor were present at the institution, which they are not. Figure 1 shows the prompt and questions as presented to the experiment participants.

To isolate the appeal of the professor from that of the course topic, analysis focused initially on the second question, "How interested would you be in taking a different class with this instructor?" Responses could be influenced by the first hypothesis with a dummy variable indicating that the professor's description identified a party and an ideology. I tested the second hypothesis by using a dummy variable indicating a match between the student and the professor's political affiliation, as well as a political-party mismatch dummy variable. I tested the third hypothesis by testing what association participants' interest had with a professor described as Republican and conservative. Further analyses divided the sample by political affiliation, always using interest in an unspecified course with the professor as the dependent variable, except for the final model in which interest in the described course is the dependent variable.

\section{SAMPLE}

The experimental instrument appeared within an omnibus experiment conducted by the Political Science and Public Administration

\section{Figure 1}

\section{Prompt and Questions Presented to Experiment Participants}

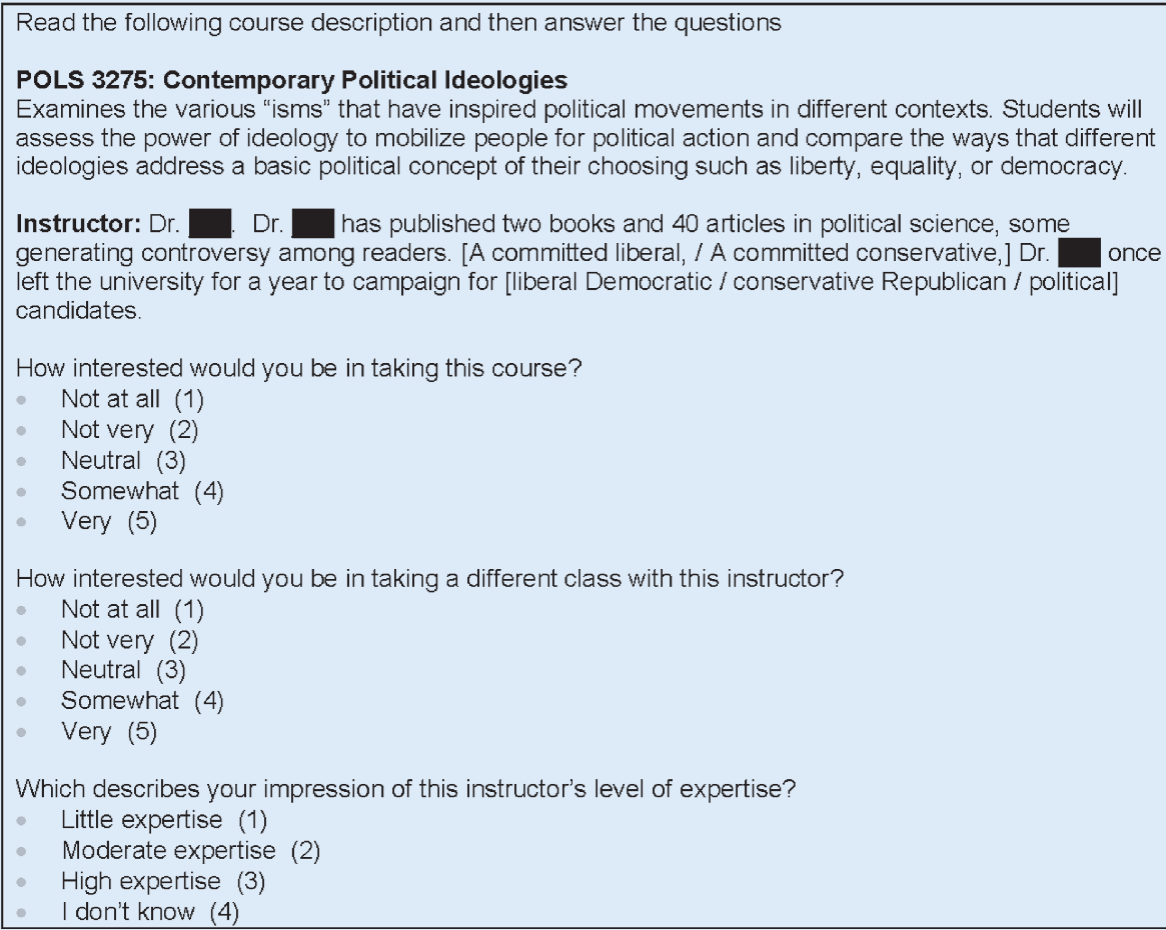
assess the power of ideology to mobilize people for political action and compare the ways that different ideologies address a basic political concept of their choosing such as liberty, equality, or democracy.

Instructor: Dr. Dr. has published two books and 40 articles in political science, some generating controversy among readers. [A committed liberal, / A committed conservative,] Dr. once left the university for a year to campaign for [liberal Democratic / conservative Republican / political] candidates

How interested would you be in taking this course?

Not at all (1)

Not very (2)

Neutral (3)

Somewhat (4)

Very (5)

How interested would you be in taking a different class with this instructor?

Not at all (1)

Not very (2)

Neutral (3)

Somewhat (4)

Very (5)

Which describes your impression of this instructor's level of expertise?

Little expertise (1)

Moderate expertise (2)

High expertise (3)

I don't know (4)

Survey software randomly assigned each participant the liberal Democratic instructor, the conservative Republican instructor, or an instructor without any indication of ideology. 
department at the University of North Carolina at Charlotte in the spring of 2018. The site of the study is a large public research institution with an acceptance rate of more than $60 \%$ and an enrollment of more than 28,00o students. On niche.com's list of Most Liberal Colleges in America, the university ranked 657 of 687 , between University of Nevada, Las Vegas, and State University of New York, Brockport. It earned a "green light" from the Foundation for Individual Rights in Education, an organization that gives this designation to schools that it views as providing strong free-speech protections. In other words, the school is not a hotbed of political activism that attracts radical students or professors and neither does its culture reflect any particular ideology. I further evaluated the context of the study by holding focus groups with campus chapters of College Republicans and College Democrats. In separate meetings, students from these groups described the university as

\section{RESULTS}

Compared to professor descriptions that were partisan, political neutrality was associated with an increase in participants' interest (model 1 in table 2). Among partisan participants, an ideological match with a professor did not increase interest over the politically neutral control condition, but a mismatch significantly reduced interest. In the third model, a conservative professor made a course less appealing to participants. In all models, conservative students were less likely to express greater interest whereas political science majors and those that followed the news were more likely to do so. Participants' gender had no significant associations.

So far, the models only control for participant ideology but do not account for how participants' responses to the main independent variable may differ by their ideology. In model 1 in table 3 , which includes all participants, conservative professors' classes were

\section{Among partisan participants, an ideological match with a professor did not increase interest over the politically neutral control condition, but a mismatch significantly reduced interest.}

“politically neutral," with most students not interested in politics and rarely attending political events.

Subjects in this online experiment were recruited mostly from introductory political science classes that fulfill a general education requirement; they participated in the study via the online Qualtrics platform. Table 1 shows selected characteristics of the sample across the three randomly assigned treatments. The study included several questions that tested participants' attention; those who did not answer questions correctly (12\%) were eliminated from the analysis. Of note are the distributions of self-identified political attributes. Slightly more than one third of the sample self-described as Democrats, slightly less than one third as Republicans, and a smaller percentage as independents. Likewise, $36 \%$ identified as liberals, $35 \%$ as conservatives, and $21 \%$ as moderate (another $8 \%$ selected "other" or "not sure"). To establish that self-identified affiliations were accurate, I compared Democrats, independents, and Republicans in their responses to several ideology-oriented questions (the results are in appendix A).

\section{Table 1}

\section{Characteristics of Experiment Participants in the Full Sample and by} Treatment Group

Full Sample Liberal Professor Treatment Control Treatment Conservative Professor Treatment

\begin{tabular}{lllll}
\hline \% Democrat & 34 & 32 & 33 & 37 \\
\hline$\%$ Republican & 32 & 38 & 28 & 31 \\
\hline$\%$ Liberal & 36 & 32 & 37 & 39 \\
\hline$\%$ Conservative & 36 & 42 & 30 & 36 \\
\hline Average Age & 21.3 & 21.2 & 21.3 & 21.4 \\
\hline$\%$ Female & 46 & 39 & 44 & 52 \\
\hline$\%$ White & 64 & 68 & 61 & 62 \\
\hline \% Following News Daily & 29 & 55 & 55 & 50 \\
\hline Political Science Majors & 20 & 29 & 32 & 26 \\
\hline
\end{tabular}


However, in the context of a politically neutral public university, the stronger avoidance of politically active conservative professors by liberal and moderate students warrants consideration.

Commentators such as Horowitz (2010) and Shapiro (2010) might argue that the results suggest that liberal students are intolerant and have come to expect universities to protect them from ideas that challenge their worldviews, whereas conservative students expect the opposite. This conclusion may go too far, however, because the behavior of independent (and moderate) students resembles more that of liberal students than conservative students (see table 3 , model 3 ).
If it were liberals' intolerance of conservative ideology that drove the lack of enthusiasm for conservative professors, we would expect to see politically neutral students respond either positively to conservative professors (reflecting $\mathrm{H}_{3}$ ) or reject both liberal and conservative professors (reflecting $\mathrm{H}_{1}$ and $\mathrm{H}_{2}$ ). However, they do neither; unaffiliated students exhibit no change when shown a liberal professor and respond negatively to a conservative professor. For some reason, skepticism toward conservative professors is more common than the third hypothesis predicted. Succinctly, openly conservative professors are polarizing, even before they give their first lecture.

Succinctly, openly conservative professors are polarizing, even before they give their first lecture.

Table 2

Odds Ratios for Expressing Greater Interest in Taking an Unspecified Course with the Professor as Described

\begin{tabular}{lccc} 
& Model1 & Model2 & Model 3 \\
\hline Neutral Professor & Neutrality & Tribalism & Hoya \\
\hline Ideological Match & $1.567^{*}(0.282)$ & & $0.972(0.184)$ \\
\hline Ideological Mismatch & & $0.257^{* * *}(0.046)$ & $0.582^{* *}(0.108)$ \\
\hline Conservative Professor & & & $0.897^{*}(0.046)$ \\
\hline Ideology (Conservatism) & $0.906^{*}(0.046)$ & $0.836^{* *}(0.046)$ & $1.482+(0.336)$ \\
\hline Political Science Major & $1.576^{*}(0.358)$ & $1.455+(0.328)$ & $1.112^{* *}(0.043)$ \\
\hline News Consumption & $1.113^{* *}(0.043)$ & $1.112^{* *}(0.043)$ & $1.041(0.186)$ \\
\hline Female & $1.016(0.181)$ & $1.104(0.199)$ & -645.861 \\
\hline Log Likelihood & -646.992 & -639.095 & 466 \\
\hline $\mathrm{N}$ & 466 & 466 & 4
\end{tabular}

Notes: ${ }^{*}<<0.05,{ }^{* *} p<0.01,{ }^{* * *} p<0.001,+p<0.10$. Standard errors in parentheses. Robustness checks are addressed in appendix C

Table 3

Odds Ratios for Expressing Greater Interest in Taking an Unspecified Course with the Professor Described, by Participants' Political Ideologies

DV=Interest in Professor

DV=Interest in Course

\begin{tabular}{lccccc}
\hline & Model 1 & Model 2 & Model 3 & Model 4 & Model 5 \\
\hline & Full Sample & Democratic Participants & Independent Participants & Republican Participants & Republican Participants \\
\hline Liberal Professor & $0.773(0.158)$ & $0.967(0.349)$ & $0.972(0.375)$ & $0.671(0.239)$ & $0.883(0.316)$ \\
\hline Conservative Professor & $0.511^{* *}(0.109)$ & $0.221^{* * *}(0.082)$ & $0.445^{*}(0.176)$ & $1.355(0.534)$ & $2.186^{*}(0.862)$ \\
\hline Ideology (conservative) & $0.901^{*}(0.046)$ & $0.847(0.125)$ & $1.038(0.153)$ & $0.927(0.133)$ & $0.993(0.139)$ \\
\hline Political Science Major & $1.523+(0.347)$ & $1.312(0.482)$ & $2.570^{*}(1.099)$ & $1.059(0.446)$ & $1.300(0.538)$ \\
\hline News Consumption & $1.111^{* *}(0.042)$ & $1.115+(0.073)$ & $1.095(0.084)$ & $1.129+(0.075)$ & $1.138+(0.076)$ \\
\hline Female & $1.040(0.186)$ & $1.018(0.315)$ & $1.175(0.397)$ & $0.969(0.307)$ & $1.122(0.351)$ \\
\hline Log Likelihood & -645.073 & -224.408 & -178.627 & -216.997 & -215.977 \\
\hline $\mathbf{N}$ & 466 & 163 & 135 & 159 & 159 \\
\hline
\end{tabular}

Notes: ${ }^{*} p<0.05,{ }^{* *} p<0.01,{ }^{* * *} p<0.001,+p<0.10$. The dependent variable for model 5 is interest in the political ideologies course. Standard errors are in parentheses. In models $1-4$, the dependent variable is expressed interest in "a different course with this professor"; however, in model 5 , the dependent variable is expressed interest in the course on contemporary political ideologies with the described professor. 
Beyond a distaste for conservatives, responses of liberal and moderate students may reflect an expectation that conservative professors will be less fair. It could be that a conservative instructor is such an anomaly that there is uncertainty about how class will be conducted. Additionally, during data collection, Republicans controlled the presidency, both chambers of Congress, and both chambers of the state legislature. Therefore, rejecting a conservative professor in this study might have been an opportunity for participants to resist the government in power or to symbolically demonstrate unity with the Left by exhibiting intolerance for the Right (Claassen and Gibson 2018). The fact that conservative students were less likely to express interest in the professor supports the notion that they want to avoid classes in which ideology will be a topic of discussion, except when it is taught by a conservative.

The significance of these findings depends on one's interests. Conservative professors contemplating being more vocal about their beliefs may earn a small, enthusiastic following but may miss class enrollment goals or the opportunity to reach liberal and moderate students. University departments contemplating affirmative action for overtly conservative professors also may note that student interest is unlikely to increase as a result. In extreme settings, professors hiding their political activity may be a necessary-however unfortunate-strategy. Finally, conservative activists might achieve their goals more easily by calling for balanced teaching rather than balanced faculties. Overall, political neutrality at least is not unpopular among students.

\section{LIMITATIONS}

In the assessments of its politically active students, the university that was the site for this study is politically neutral. Although the advantage of this location is that the immediate political environment was unlikely to affect interpretations of treatments, students' reactions to political professors could differ in other places, especially where the political climate is more salient. Results are not generalizable.

\section{SUPPLEMENTARY MATERIAL}

To view supplementary material for this article, please visit https://doi.org/10.1017/S104909651900194X

\section{ACKNOWLEDGMENTS}

The author thanks Dr. Cherie Maestas, Dr. Matthew Cawvey, and the POLS Lab at UNC Charlotte for conducting the omnibus experiments that produced the data for this research.

\section{NOTE}

1. For associations between students' ideologies and course of study, see Porter and Umbach (2006).

\section{REFERENCES}

Abramowitz, Alan I., and Steven W. Webster. 2018. "Negative Partisanship: Why Americans Dislike Parties but Behave Like Rabid Partisans.” Political Psychology 39 (S1): 119-35. Available at https://doi.org/10.1111/pops.12479.

Acker, James R. 2003. "Class Acts: Outstanding College Teachers and the Difference They Make." Criminal Justice Review 28: 215-31.
Barr, Andrew, and Sarah E. Turner. 2013. "Expanding Enrollments and Contracting State Budgets: The Effect of the Great Recession on Higher Education." The Annals of the American Academy of Political and Social Science 650 (1): 168-93. Available at https://doi.org/10.1177/0002716213500035.

Bloom, Allan. 1987. The Closing of the American Mind: How Higher Education Has Failed Democracy and Impoverished the Souls of Today's Students. New York: Simon \& Schuster.

Buckley, William F. 1951. God and Man at Yale: The Superstitions of "Academic Freedom." Chicago: Regnery Publishing.

Claassen, Christopher, and James L. Gibson. 2018. "Does Intolerance Dampen Dissent? Macro-Tolerance and Protest in American Metropolitan Areas." Political Behavior 41 (1): 165-85.

Eagan, Kevin, Ellen Bara Stolzenberg, Hilary B. Zimmerman, Melissa C. Aragon, Hannah Whang Sayson, and Cecilia Rios-Aguilar. 2017. "The American Freshman: National Norms, Fall 2016." Los Angeles: University of California Higher Education Research Institute.

Friedersdorf, Conor. 2012. "Admit It, American Colleges Do Indoctrinate Students." The Atlantic, February 27. Available at www.theatlantic.com/politics/archive/2012/02/ admit-it-american-colleges-do-indoctrinate-students/253607.

Gift, Karen, and Thomas Gift. 2015. "Does Politics Influence Hiring? Evidence from a Randomized Experiment.” Political Behavior 37 (3): 653-75.

Gormley-Heenan, Cathy. 2012. "Teaching Politics and Political Bias." In Teaching Politics and International Relations, ed. Cathy Gormley-Heenan and Simon Lightfoot, 132-45. London: Palgrave Macmillan.

Gross, Neil. 2013. Why Are Professors Liberal and Why Do Conservatives Care? Cambridge, MA: Harvard University Press.

Gross, Neil, and Solon Simmons (eds.). 2014. Professors and their Politics. Baltimore: Johns Hopkins University Press.

Horowitz, David. 2010. Reforming Our Universities: The Campaign for an Academic Bill of Rights. New York: Simon \& Schuster.

Kelly-Woessner, April, and Matthew Woessner. 2006. "My Professor Is a Partisan Hack: How Perceptions of a Professor's Political Views Affect Student Course Evaluations.” PS: Political Science \& Politics 39 (3): 495-501.

Kelly-Woessner, April, and Matthew Woessner. 2008. "Conflict in the Classroom: Considering the Effects of Partisan Difference on Political Education." Journal of Political Science Education 4 (3): 265-85.

Mariani, Mack D., and Gordon J. Hewitt. 2008. "Indoctrination U.? Faculty Ideology and Changes in Student Political Orientation." PS: Political Science E Politics 41 (4): $773-83$.

Miron, Mordechai, and Esther Segal. 1978. "The Good University Teacher." Higher Education 1 (7): 27-34.

O’Brien, Timothy L., and Oren Pizmony-Levy. 2016. "Going Public, Gaining Credibility: Student Perceptions of Publicly Engaged Scholars." Sociological Perspectives 59 (2): 246-69.

Porter, Stephen R., and Paul D. Umbach. 2006. "College Major Choice: An Analysis of Person-Environment Fit." Research in Higher Education 47 (4): 429-49.

Rothman, Stanley, April Kelly-Woessner, and Matthew Woessner. 2010. The Still Divided Academy: How Competing Visions of Power, Politics, and Diversity Complicate the Mission of Higher Education. Blue Ridge Summit, PA: Rowman \& Littlefield.

Shapiro, Ben. 2010. Brainwashed: How Universities Indoctrinate America's Youth. Nashville, TN: WND Books.

Shields, Jon A., and Joshua M. Dunn. 2016. "Do Universities Need Affirmative Action for Conservative Professors?" Los Angeles Times, March 18. Available at www.latimes.com/opinion/op-ed/la-oe-0320-shields-dunn-conservativeaffirmative-action-20160320-story.html.

Slate, John R., Kimberly LaPrairie, and Anthony J. Onwuegbuzie, 2009. "A Mixed Analysis of College Students' Best and Poorest College Professors." Issues in Educational Research 19 (1): 61-78.

Tinto, Vincent. 2017. "Reflections on Student Persistence." Student Success 8 (2): 1-8.

Woessner, Matthew, and April Kelly-Woessner. 2009. "I Think My Professor Is a Democrat: Considering Whether Students Recognize and React to Faculty Politics." PS: Political Science \& Politics 42 (2): 343-52.

Wooldridge, Adrian. 2005. "The Brains Business: A Survey of Higher Education." Economist Newspaper, September 10. Available at www.economist.com/specialreport/2018/08/14/the-brains-business.

Young, Suzanne, and Dale G. Shaw. 1999. "Profiles of Effective College and University Teachers." Journal of Higher Education 70: 670-86. 